\title{
EVALUATION OF IN VIVO IMMUNOMODULATORY ACTIVITY OF AQUEOUS AND ETHANOLIC EXTRACT OF CAPPARIS MOONII
}

\section{VANITA G KANASE*, SHRUTI SHETTIGAR}

Department of Pharmacology, Oriental College of Pharmacy, Navi Mumbai, Maharashtra, India. Email: vanita.kanase@gmail.com

Received: 10 October 2019, Revised and Accepted: 02 April 2020

\section{ABSTRACT}

Objective: The present study was intended to evaluate the in vivo immunomodulatory activity of aqueous and ethanolic extract of dried fruits of Capparis moonii Wight.

Methods: The effect of both the extracts was evaluated by carbon clearance assay in mice, and they showed a significant increase in the phagocytic index at 50,100, and $200 \mathrm{mg} / \mathrm{kg}$ dose. The effect of the extracts on delayed-type hypersensitivity (DTH) and antibody titer assay was evaluated in ovalbumin immunized mice.

Results: Both extracts showed a significant effect on DTH response and stimulation of antibody titer at $200 \mathrm{mg} / \mathrm{kg}$ dose. The effects of the extracts in cyclophosphamide-induced myelosuppression mice were also statistically significant.

Conclusion: The studies demonstrated specific and non-specific immunostimulating properties of both the ethanol and aqueous extract of $C$. moonii fruits in various in vivo experimental methods suggesting its therapeutic usefulness in immunocompromised conditions.

Keywords: Capparis moonii, Carbon clearance, Ovalbumin antibody titer, Cyclophosphamide myelosuppression.

(C) 2020 The Authors. Published by Innovare Academic Sciences Pvt Ltd. This is an open access article under the CC BY license (http://creativecommons. org/licenses/by/4. 0/) DOI: http://dx.doi.org/10.22159/ajpcr.2020.v13i6.36031

\section{INTRODUCTION}

Immunomodulation is a transition in the immunological network of the body and an immunomodulator would be the agent which can interfere with this immunological network to stimulate or suppress certain characteristics of the host response [1,2]. It is understood that the immune system is having its role in both the etiology and the pathophysiological processes of many diseases [3]. The idea of immune therapies has presently grown as a novel testing path that changes even the characteristics of chemotherapy [4]. Ayurveda places emphasis on health promotion - a philosophy of reinforcing host defenses against various diseases [5]. Rasayana plants are primarily recommended for the treatment of immune disorder [6], and Ayurveda (with special regard to plants) may play a key role in modern health care, especially where there is no satisfactory treatment. Developing agents that can move the immune system of the patient from a state of immune deficiency to one of the more normal functions would likely have a major effect on the disease and the patient. These agents would not be a cure but would monitor disease progression and course [7]. The family of Capparaceae consists of several essential medicinal characteristics, which is found to be distributed in tropical and subtropical India. Plants pertaining to this family were characterized as Rasayana herbs and are used widely as an adaptogen to boost non-specific antioxidant resistance and immunostimulation effects. The Clarkeulia sepiaria, Caesalpinia spinosa, Carya tomentosa, Capparis zeylanica, Capparis moonii, etc., are reported to belong to this family according to their usage in traditional medicine [8]. C. moonii Wight, widely known as Large Caper, Rudanti in Sanskrit, and Waghati in Marathi, is dispersed in Maharashtra, Goa, Karnataka, Kerala, and Tamil Nadu. Large Caper is the biggest of all caper flowers. Sitosterol, stachyhydrin, rutin, and gallotannins (chebulinic acid derivatives) are the primary active compounds existing in Rudanti fruits. Curative uses of Rudanti in Ayurveda: Rudanti nurtures each and every cell of the body (Rasayani). It is effective under dietary and emaciating (Shoshghani) situations. This prevents the signs of aging (Jara Vinashnam) and is also beneficial in diseases that devastate all body systems (Rajyakshma Shasyate). Rudanti was also widely used by the people of India to get relief from asthma and cough. It demonstrated substantial antitussive activity as that of codeine phosphate in the cough model induced by sulfur dioxide gas compared with dose-dependent control [9]. Bioassay directed fractionation of the $C$. moonii fruit hydroalcoholic extract led to the isolation of two new derivatives of chebulinic acid. Compounds 1 and 2 showed a remarkable glucose uptake effect of $223 \%$ and $219 \%$ over control at concentrations of $10 \mathrm{ng} / \mathrm{ml}$ and $100 \mathrm{ng} / \mathrm{ml}$, respectively. The enhanced effects of the compounds on glucose uptake were linked to increased phosphorylation of insulin receptor (IR) and IR substrate 1 , glucose transporter type 4 , and phosphoinositide kinase messenger ribonucleic acid expression in the L6 cells [10]. The result of the $C$. moonii Hook F. Thomas ethanolic extract of was tested for hepatotoxicity in rats caused by carbon tetrachloride $\left(\mathrm{CCl}_{4}\right)$. The hepatotoxicity was triggered on day 7 in rats with the administration of 1:1 volume/volume (v/v) $\mathrm{CCl}_{4}$ mixture in olive oil subcutaneously at a dose of $1 \mathrm{ml} / \mathrm{kg}$. The ethanolic extract from C. moonii $(200 \mathrm{mg} / \mathrm{kg})$ and the standard drug silymarin $(25 \mathrm{mg} / \mathrm{kg})$ were administered per oral (p.o.) from day 1 to day 9. The $C$. moonii extract produced prominent $(\mathrm{p}<0.001)$ decreases in serum glutamic oxaloacetic transaminase, serum glutamic pyruvate transaminase, alkaline phosphatase, and an increase in total depleted protein compared to toxic control. The results were comparable to that of standard silymarin drugs. Carbon-tetrachloride-mediated hepatotoxicity prevention by $C$. moonii ethanolic extracts in rats was observed [11]. C. moonii's immunomodulatory response was not examined to our awareness. The primary goal of this research was to determine the in vivo immunomodulatory activity of $C$. moonii's aqueous and ethanolic extract.

\section{METHODS}

\section{Plant material and preparation of extract}

C. moonii fruits were purchased from a local supplier in January 2012 and authenticated from Agharkar Research Institute located at Pune in India $[12,13]$. The voucher specimen (No. F-176) was deposited in the herbarium of the Institute for future reference. Little sections were cut down and dried at a controlled temperature $45^{\circ} \mathrm{C}$ and powdered. The powder was extracted with ethanol under soxhlation to give an ethanolic extract of fruits of $C$. moonii (CME) and similarly with water under soxhlation to give an aqueous extract of fruits of $C$. moonii (CMA). The extract was filtered and evaporated to dryness. 
Preliminary phytochemical screening

The aqueous and ethanolic extracts of $C$. moonii fruits were subjected to preliminary phytochemical screening [14] for the detection of various plant constituents.

\section{Experimental animals}

Animals used were mice (Swiss Albino) which were obtained from National Toxicology Centre (NTC), Pune. The animals were kept for acclimatization for 10 days before being used for the experiments. They were housed in a room with controlled temperature $\left(23 \pm 2^{\circ} \mathrm{C}\right)$ and a 12 -h light/12-h dark cycle. The animals were fed with standard pellet diet and water. The experimental protocols were approved by the Institutional Animal Ethics Committee of the NTC, Pune, and conducted according to the guidelines of the Committee for the Purpose of Control and Supervision on Experiments on Animals, India (Research project No. 159) at NTC Laboratory Pune.

\section{Acute oral toxicity studies}

Acute oral toxicity studies were carried out for CMA and CME of dried fruits of $C$. moonii as per the Organization for Economic Cooperation and Development guideline number 423 [15].

\section{Chemicals}

Ovalbumin, Freund's Complete Adjuvant (FCA), Bovine Serum Albumin (BSA), was procured from Bangalore Genei Ltd., India. Phytohemagglutinin-M (PHA) and fetal bovine serum were obtained from Sigma Aldrich at Saint Louis present in the United States of America. All other chemicals used were of grade use for analytical purposes [16].

\section{In vivo model for phagocytic activity using the carbon clearance} assay

Phagocytic activity of both extracts was determined as per the method described earlier [17]. Mice were divided into nine groups of six each. The vehicle control group received $0.5 \%$ sodium carboxymethyl cellulose (NaCMC). The standard group received (immunosin $50 \mathrm{mg} / \mathrm{kg}$ ). Negative control group received cyclophosphamide (CYP) $10 \mathrm{mg} / \mathrm{kg}$. Mice in the test categories were administered with orally CMA and CME extract each $(50,100$, and $200 \mathrm{mg} / \mathrm{kg})$ suspended in the vehicle daily for 20 days. Carbon solution in the form of colloid, Rotring ink ${ }^{\circledR}$ from Hamburg in Germany, was made less concentrated with saline and injected through a tail vein in each animal for $24 \mathrm{~h}$ after the last dose. Blood was procured from retro-orbital plexus under anesthesia of ether at 2 and $15 \mathrm{~min}$ after injection. From this sample, $25 \mu \mathrm{l}$ was added along with $2 \mathrm{ml} 0.1 \%$ sodium carbonate for the breakdown of red blood corpuscles (RBCs). Optical density (OD) was recorded at 660 $\mathrm{nm}$. Formula used for calculation of the phagocytic index $(\mathrm{K})$ was $\mathrm{K}=(\mathrm{ln}$ $\left.\mathrm{OD}_{1}-\ln \mathrm{OD}_{2}\right) /\left(\mathrm{T}_{2}-\mathrm{T}_{1}\right)$, where $\mathrm{OD}_{1}$ and $\mathrm{OD}_{2}$ are the optical densities at times $\mathrm{T}_{1}(2 \mathrm{~min})$ and $\mathrm{T}_{2}(15 \mathrm{~min})$, respectively [18].

\section{Immunization and treatment}

Animals were initially grouped into nine categories where each contained six animals. The control group received ( $0.5 \% \mathrm{NaCMC})$, standard group received (immunosin $50 \mathrm{mg} / \mathrm{kg}$ ). Disease control group received CYP 10 $\mathrm{mg} / \mathrm{kg}$ ), while mice in the treatment groups were administered with the CMA and CME extract each $(50,100$, and $200 \mathrm{mg} / \mathrm{kg}$, p.o.) in the vehicle daily for 20 days. On the $14^{\text {th }}$ day, the animals were given immunization by a subcutaneous route with ovalbumin ( $3 \mathrm{mg}$ ) dissolved in normal saline emulsified with an equal volume of FCA.

\section{Delayed type hypersensitivity (DTH) response}

To assess the DTH response, mice were challenged subcutaneously with $25 \mu \mathrm{g}$ ovalbumin in $25 \mu \mathrm{l}$ normal saline in the left hind footpad for 7 days after the immunization. The right hind footpad was injected with $25 \mu \mathrm{l}$ vehicle and served as control. The increase in the thickness of footpad was estimated $24 \mathrm{~h}$ after the challenge with the help of a Digimatic Caliper by Mitutoyo Corporation in Japan.

\section{Detection of serum antibody response}

The animal blood sample was taken by retro-orbital plexus after 7 days of immunization and serum was separated under centrifugation. Serum antibody titers for quantification of serum immunoglobulin G (IgG) to ovalbumin were estimated by ELISA, as described earlier. Polystyrene plates having a bottom that is flat were layered with $12.5 \mu \mathrm{g}$ of ovalbumin in $100 \mu \mathrm{l}$ of sodium carbonate buffer $\left(\mathrm{pH} \mathrm{9.6)}\right.$ ) at $4^{\circ} \mathrm{C}$ for $12 \mathrm{~h}$. The layered plates were 3 times washed with phosphate buffer saline (0.15 M, pH 7.2) containing TWEEN-20 (PBS-Tw) about $0.05 \%$. There was then incubation of the wells with $100 \mu \mathrm{l}$ of $1 \%$ BSA in sodium carbonate buffer at $37^{\circ}$ for 1 h. Dilutions of serum samples in PBS-Tw were made and $100 \mu \mathrm{l}$ was put in incubation with layered wells for $1 \mathrm{~h}$ at $37^{\circ}$. After washing, diluted (1:2000) antimouse IgG conjugated with peroxidase $(100 \mu \mathrm{l})$ was added and the plates were kept for incubation at $37^{\circ}$ for $1 \mathrm{~h}$. The enzyme activity was determined by the addition of tetramethylbenzidine/hydrogen peroxide. The reaction of enzyme was halted by adding $50 \mathrm{ml}, 8 \mathrm{~N}$ sulfuric acid and the absorbance was measured at $450 \mathrm{~nm}$. Endpoint of antibody titer was denoted in the form of reciprocal of the peak dilution of the test serum samples showing 3 times more OD as compared with control samples.

\section{CYP-induced myelosuppression}

This experiment was studied according to the procedure described earlier with some modifications. Animals were segmented into nine categories of each containing six. The vehicle control group received ( $0.5 \% \mathrm{NaCMC}$ ); standard group received (immunosin $50 \mathrm{mg} / \mathrm{kg}$ ). Disease control group received CYP $25 \mathrm{mg} / \mathrm{kg}$, whileanimals in the testcategorieswereadministered with the CMA and CME extract each (50,100, and $200 \mathrm{mg} / \mathrm{kg}$, p.o.) in vehicle daily for 19 days. On 17-10 days of study, all the mice except in the control category were administered with CYP (25 mg/kg, intraperitoneal) $1 \mathrm{~h}$ after administration of the extract or vehicle. Blood samples were collected on day 20 and total count of cells in blood was estimated utilizing a hematology analyzer from Arcus, Diatron, Wien, Austria [16,19,20].

\section{Statistical analysis}

Results are denoted as mean \pm standard error of the mean. Data were interpreted by one-way ANOVA thereafter using Tukey-Kramer multiple comparisons test. $\mathrm{p}<0.05$ is the criterion for significance.

\section{RESULTS}

\section{Extraction}

The yield of CME and CMA extract obtained 9.5\% weight/weight $(\mathrm{w} / \mathrm{w})$ and $11 \% \mathrm{w} / \mathrm{w}$, respectively. Extract displayed the appearance of phytosterols, saponins, proteins, alkaloids, glycosides, and flavonoids.

\section{In vivo model for phagocytic activity using the carbon clearance} assay

The result of CMA and CME extract was determined by the clearance assay in animals. The results are displayed in Fig. 1. The phagocytic index $(\mathrm{K})$ for CMA extract was significantly higher $(\mathrm{p}<0.01)$ at $50 \mathrm{mg} / \mathrm{kg}$ (19\%), $100 \mathrm{mg} / \mathrm{kg}$ (35.34\%), and $200 \mathrm{mg} / \mathrm{kg}(49.52 \%)$ and for CME extract was significantly higher $(\mathrm{p}<0.01)$ at $50 \mathrm{mg} / \mathrm{kg}(15.9 \%)$, $100 \mathrm{mg} / \mathrm{kg}$ (35.2\%), and $200 \mathrm{mg} / \mathrm{kg}$ (46.34\%) dose levels as compared to the control group. Positive control immunosin (50 mg/kg) showed $71.22 \%$ higher K compared to the control category.

\section{DTH response in mice immunized by ovalbumin}

To examine effect of CMA and CME extract on cellular immune system, its activity was investigated as DTH reaction to ovalbumin immunized mice. The DTH response, i.e., deviation in thickness of the footpad of animals, is represented in Fig. 2. Both aqueous and ethanolic extracts produced a significant increase in the DTH response to ovalbumin at all the tested dose levels. Elevation in DTH reaction in the animal in counter to cell-mediated response-dependent antigen revealed the stimulatory effect of the aqueous and ethanolic extract on T cells. CMA and CME 100 and $200 \mathrm{mg} / \mathrm{kg}$ also showed a significant amount of activity similar to that of Immunosin 50 $\mathrm{mg} / \mathrm{kg}$ which is positive control with a value of significance of $\mathrm{p}<0.01$.

\section{Detection of serum antibody response to ovalbumin}

Humoral response to ovalbumin was studied by enzyme-linked immunosorbent assay (ELISA) antibody titer assay. Mice treated with different doses of the CMA and CME extract showed an increase in the antibody titer in a dose-dependent pattern. There was a significant increase in serum antibody titer at $200 \mathrm{mg} / \mathrm{kg}(938.66)(\mathrm{p}<0.01)$ of CMA extract compared to control category (213.33) and a significant increase in serum antibody titer at $200 \mathrm{mg} / \mathrm{kg}(853.33)(\mathrm{p}<0.01)$ of CME extract compared to 
control category (213.33) in Fig. 3. Positive control immunosin ( $50 \mathrm{mg} / \mathrm{kg}$ ) showed $(1194.00)(\mathrm{p}<0.01)$ compared to the control group.

\section{CYP-induced myelosuppression}

There was a significant reduction $(\mathrm{p}<0.01)$ in total white blood corpuscles (WBC) count of CYP $(25 \mathrm{mg} / \mathrm{kg})$-treated mice $\left(8.792 \times 10^{3} \mathrm{cells} / \mathrm{cmm}\right)$ in comparison with the vehicle control group $\left(13.38 \times 10^{3}\right.$ cells $\left./ \mathrm{cmm}\right)$. CYP $(25 \mathrm{mg} / \mathrm{kg})$ resulted in a notable decrease in the white blood cells, red blood cells, platelet count, and hemoglobin. Combined treatment of (CMA+CYP- $25 \mathrm{mg} / \mathrm{kg}$ ) and (CME+CYP- $25 \mathrm{mg} / \mathrm{kg})(50,100$, and $200 \mathrm{mg} / \mathrm{kg})$ doses of CMA and CME each with $25 \mathrm{mg} / \mathrm{kg}$ resulted in restoration of bone marrow activity as compared with CYP treatment alone (Figs. 1-4).

\section{DISCUSSION}

Immunomodulation aids in the maintenance of a state where there are no diseases. Substances that help start the pathways of host defenses in the midst of an impaired immune response may provide encouraging therapy for traditional chemotherapy [21]. There is an increasing desire for recognizing herbal immunomodulators since suggestions have been made for their potential use in modern medicine [22]. The study's main purpose was to examine the immunomodulatory activity of the $C$. moonii aqueous and ethanolic extract.

The rise in carbon clearance, i.e., the CMA and CME extract phagocytic index represents the non-specific immunity. This suggests that extract from CMA and CME has been able to activate the phagocytic index in vivo. The impact of the CMA and CME extract on cell-mediated immunity (CMI) was assessed with a delayed-type hypersensitivity reaction to ovalbumin, a cell-mediated response-dependent antigen. CMI reactions are important for defending against infectious agents, foreign graft invasion, tumor defense, and DTH reaction [23]. Accordingly, an increase in DTH reaction in mice in response to cell-mediated response based antigen reported the stimulating effect of $C$. moonii ethanolic and aqueous extract. The results are displayed in Figs. 4-7. The interaction of cell-mediated response and humoral response

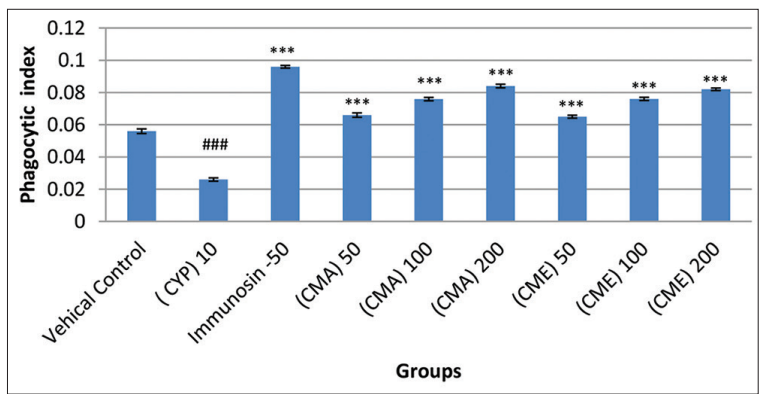

Fig. 1: In vivo model for phagocytic activity using the carbon clearance assay: Values are expressed as mean \pm standard error of the mean $(\mathrm{n}=6) .{ }^{* * *} \mathrm{p}<0.001$ compared with toxicant control, ${ }^{\# \# \#} \mathrm{p}<0.001$ compared with vehicle control. Data were analyzed using one-way

ANOVA followed by Tukey-Kramer multiple comparisons test

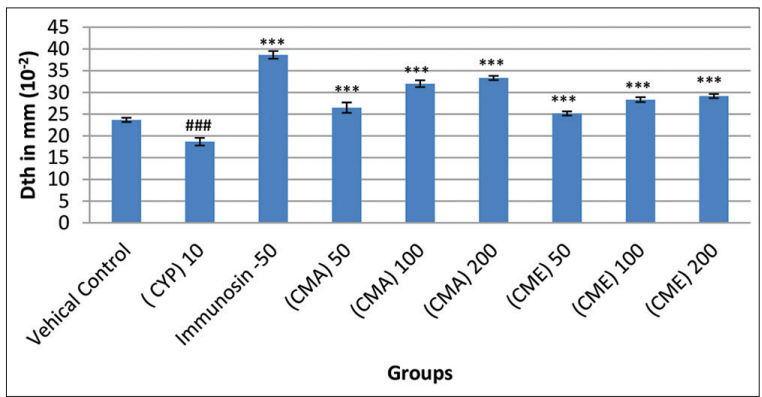

Fig. 2: Delayed type hypersensitivity response: Values are expressed as mean \pm standard error of the mean $(n=6) . * * *<<0.001$ compared with toxicant control, \#\#\#p<0.001 compared with vehicle control. Data were analyzed using one-way ANOVA followed by Tukey-Kramer multiple comparisons test offers an efficient trigger for the segregation of B lymphocytes and for the antibody production against the cell-mediated response-dependent antigen (ovalbumin) [24]. Raising the humoral immune response by CMA and CME extract to ovalbumin, as indicated by growing the antibody titer in mice, demonstrated the increased sensitivity of $\mathrm{T}$ and $\mathrm{B}$ lymphocyte subgroups participating in the production of the antibody.

A greater level of cell growth makes the marrow specifically a responsive target for anti-neoplastic drugs. In fact, the marrow is the most influenced organ, particularly with CYP, throughout any immunosuppressive therapy. Destruction of stem cells and the marrow's failure to produce fresh blood cells contributes to thrombocytopenia and leucopenia [25]. As C. moonii increased the circulated titer of the antibody, evaluating its impact on blood count in the periphery and induced immunosuppression by CYP was considered valuable. C. moonii treatment substantially increased total WBC count, RBC count, hemoglobin count, and platelet count, as well as reversed the CYP-induced myelosuppressive impact. The current study indicates that $C$. moonii can activate immune responses, both cell and humoral mediated. More experiments have to be performed to illustrate the precise immunostimulatory function of $C$. moonii.

\section{CONCLUSION}

The studies have demonstrated specific and non-specific immunostimulating properties of both the ethanol and aqueous extract of $C$. moonii fruits in various in vivo experimental methods. This suggests its therapeutic usefulness in immunocompromised conditions.

\section{ACKNOWLEDGMENT}

We authors are pleasured to thank the authority, APT Research Foundation, National Toxicology Centre, Pune, Maharashtra, India, for permitting us to conduct in vivo studies in their laboratory.

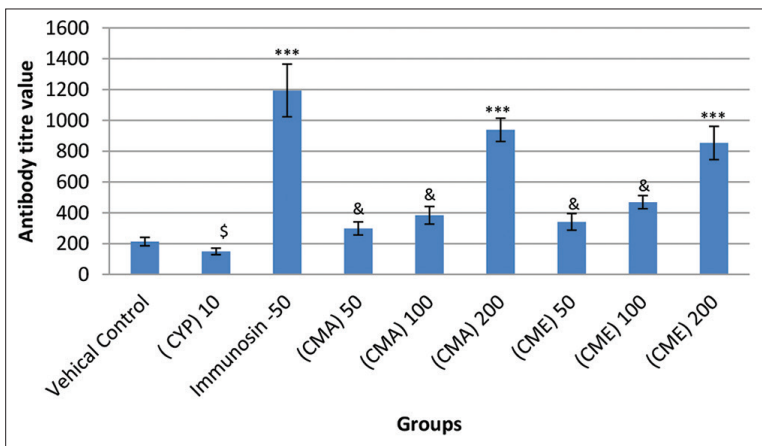

Fig. 3: Detection of serum antibody response: Values are expressed as mean \pm standard error of the mean $(\mathrm{n}=6){ }^{* * *} \mathrm{p}<0.001$ compared with toxicant control, ${ }^{s} p>0.05$ compared with vehicle control and $p>0.05$ compared with vehicle control. Data were analyzed using one-way

ANOVA followed by Tukey-Kramer multiple comparisons test

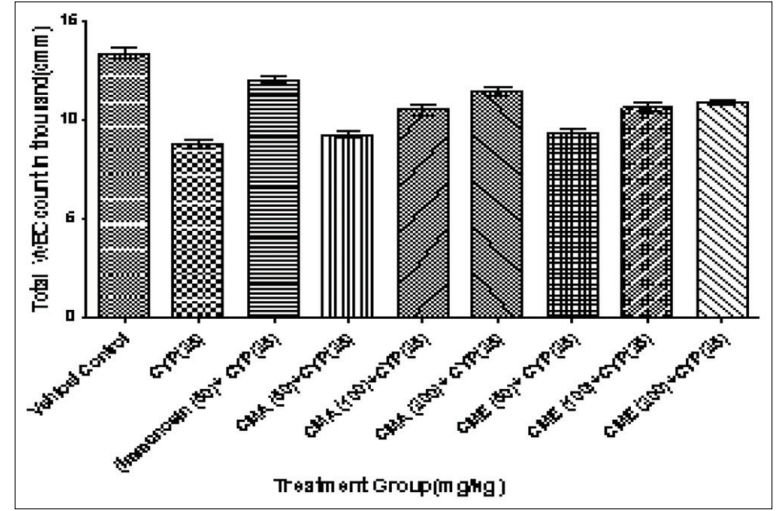

Fig. 4: Changes in white blood corpuscles count with cyclophosphamide-induced myelosuppression ethanolic extract of fruits of Capparis moonii, aqueous extract of fruits of $C$. moonii 


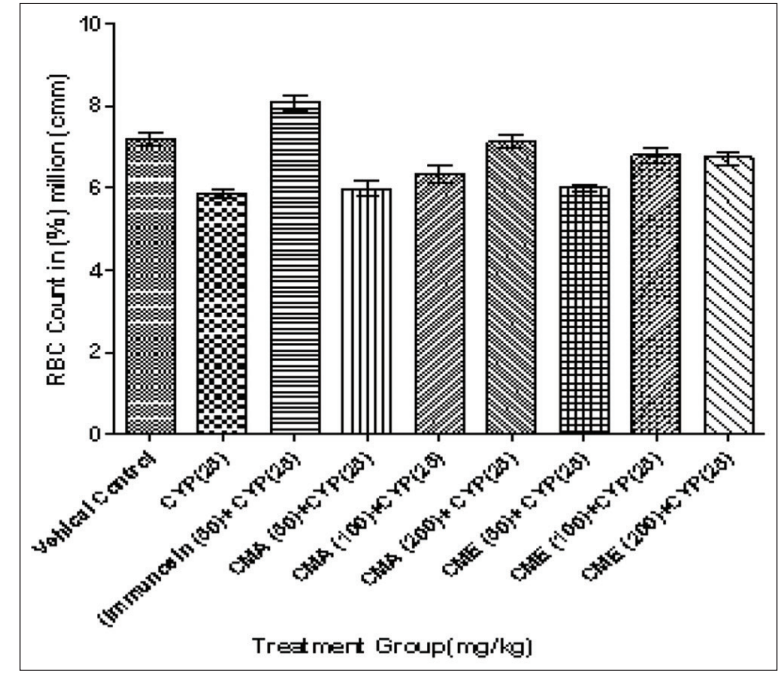

Fig. 5: Changes in red blood corpuscles count with cyclophosphamide-induced myelosuppression ethanolic extract of fruits of Capparis moonii, aqueous extract of fruits of $C$. moonii

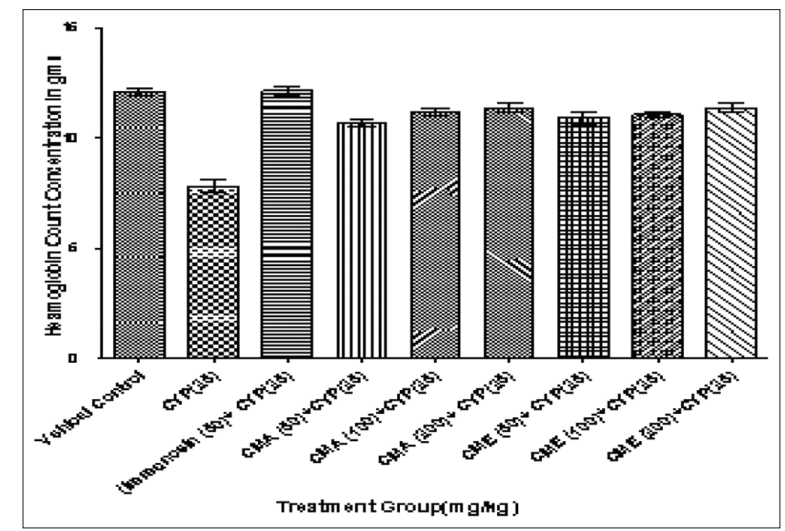

Fig. 6: Changes in hemoglobin with cyclophosphamide-induced myelosuppression ethanolic extract of fruits of Capparis moonii, aqueous extract of fruits of $C$. moonii

\section{AUTHORS' CONTRIBUTIONS}

The authors declare that this work was done by the authors named in this article.

\section{AUTHORS' FUNDING}

We thank Oriental College of Pharmacy for funding the project.

\section{CONFLICTS OF INTEREST}

There are no conflicts of interest.

\section{REFERENCES}

1. Akula A, Vishala C, Pitchaiah G. Immunomodulatory activity of nutraceutical formulation and its potentiation by self-fortification and cow urine distillate fortification methods. Int J Pharm Pharm Sci 2017;9:15-9.

2. Thadhani VM, Mesaik MA, Asif M, Karunaratne V, Choudhary IM. Immunomodulatory activities of some common lichen metabolites. Int J Pharm Pharm Sci 2015;7:144-7.

3. Sharma P. Charaka Samhita, Chikitasa Sthana. Varanasi, India: Chaukhambha Orientalia; 1983. p. 54.

4. Sulaiman AA, Al-Shamaa ZA, Al-Assadi ME. Evolving role of car T-cell in cancer immunotherapy. Int J Curr Pharm Res 2019;11:19-27.

5. Thatte UM, Dahanukar SA. Ayurveda and contemporary scientific thought. Trends Pharmacol Sci 1986;7:247-51.

6. Wagner H, Dahanukar SA, Thatte UM, Rege NM. Immunomodulatory Agents from Plants. Basel, Switzerland: Birkhauser; 1999. p. 289-323.

7. Gottlieb AA, Gottlieb MS, Scholes VE. Reconstitution of immune

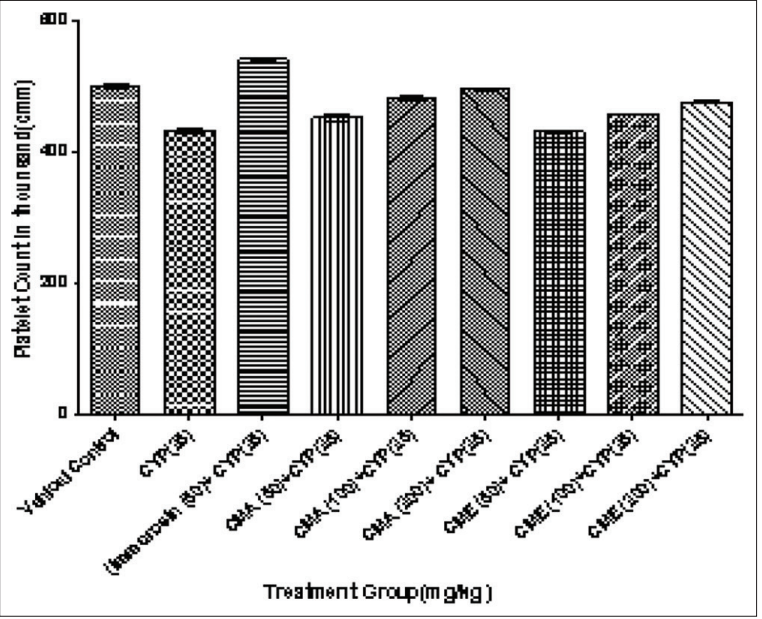

Fig. 7: Changes in platelet count with cyclophosphamide-induced myelosuppression ethanolic extract of fruits of Capparis moonii, aqueous extract of fruits of $C$. moonii

functions in AIDS/ARC. Concepts Immunopathol 1987;4:261-74.

8. Rajesh P, Selvamani P, Latha S, Saraswathy A, Rajesh KV. A review on chemical and medicobiological applications of capparidaceae family. Pharmacogn Rev 2009;3:378-87.

9. Sunita P, Jha S, Pattanayak SK. In vivo antitussive activity of Cressa cretica Linn. using cough model in rodents. Pharmacogn Res 2009;1:157-61.

10. Lakshmi B, Kanaujia SA, Duggar R, Pannakal ST, Yadav SS, Katiyar CK, et al. Insulinomimetic activity of two new gallotannins from the fruits of Capparis moonii. Bioorg Med Chem 2010;18:3940-5.

11. Ali M, Ramachandram R, Rafiullah MR, Singh O, Siddiqui AW, Mir SR. Prevention of carbon-tetra-chloride induced hepatotoxicity by the ethanolic extract of Capparis moonii in rats. Pharm Biol 2004;42:286-8.

12. Kanase VG, Dhotre G, Jain K, Shettigar S, Gupta R, Patil DT, et al. Evaluation of antiulcer activity of aqueous extract of Capparis moonii of Albino rats. World J Pharm Pharm Sci 2017;7:873-83.

13. Kanase VG, Dhotre G, Jain K, Shettigar S, Gupta R, Patil DT, et al. Evaluation of anti-inflammatory and anti-pyretic activity of ethanolic extract of Capparis Moonii in Albino rats. Eur J Biomed Pharm Sci 2018;5:464-9.

14. Trease GE, Evans W. Text book of Pharmacognosy. $12^{\text {th }}$ ed. London: Bailliere, Tindall; 1983. p. 343-83.

15. Organization for Economic Co-operation and Development. 1987, OECD Guidelines for Testing Chemicals, Guideline 423: Acute Oral Toxicity. Paris: Organization for Economic Co-operation and Development; 2001. p. 1-14.

16. Kanase V, Patil DT. Evaluation of in vivo immunomodulatory activity of aqueous and ethanolic extract of Eulophia nuda L. Asian J Pharm Clin Res 2018;11:374-9.

17. Yan Y, Wanshun L, Baoqin H, Changhong W, Chenwei F, Bing L, et al. The antioxidative and immunostimulating properties of D-glucosamine. Int Immunopharmacol 2007;7:29-35.

18. Lee S, Suk K. Heme oxygenase-1 mediates cytoprotective effects of immunostimulation in microglia. Biochem Pharmacol 2007;74:723-9.

19. Shah AS, Wakade AS, Juvekar AR. Immunomodulatory activity of methanolic extract of Murraya koenigii (L) Spreng. Leaves. Indian J Exp Biol 2008;46:505-9.

20. Ghule BV, Murugananthan G, Nakhat PD, Yeole PG. Immunostimulant effects of Capparis zeylanica Linn. Leaves. J Ethnopharmacol 2006;108:311-5.

21. Wagner H, Hiroshi H, Farnsworth NR, editors. Immunostimulatory drugs of fungi and higher plants. In: Economic and Medicinal Plant Research. Vol. 1. London: Academic Press; 1984. p. 113-53.

22. Tiwari U, Rastogi B, Singh P, Saraf DK, Vyas SP. Immunomodulatory effects of aqueous extract of Tridax procumbens in experimental animals. J Ethnopharmacol 2004;92:113-9.

23. Miller LE, Ludke HR, Peacock, JE, Tomar RH, editors. Manual of Laboratory Immunology. London: Lea and Febiger; 1991. p. 1-18.

24. Stanilova SA, Zhelev ZD, Dobreva ZG. Preliminary studies on the immunomodulatory effect of the $\mathrm{C} 3$ binding glycoprotein isolated from Cuscuta europea. Int J Immunopharmacol 2000;22:15-24.

25. Agarwal R, Diwanay S, Patki P, Patwardhan B. Studies on immunomodulatory activity of Withania somnifera (Ashwagandha) extracts in experimental immune inflammation. J Ethnopharmacol 1999;67:27-35. 